\title{
Childhood Seeligmüller Strümpell Philip Disease: The First Case in Iraq and a Review of the Early Historic Documentation of the Disease in the
} Literature

\author{
Al-Mosawi $\mathrm{AJ}^{1,2^{*}}$
}

${ }^{1}$ Advisor in Pediatrics and Pediatric Psychiatry, Children Teaching Hospital of Baghdad Medical City, Baghdad, Iraq

${ }^{2}$ Head, Iraq Headquarter of Copernicus Scientists International Panel, Baghdad, Iraq

Corresponding Author: Aamir Jalal Al Mosawi ${ }^{\text {ORCID ID }}$

Address: Department of Pediatrics, Children Teaching Hospital, Baghdad Medical City, Baghdad, Iraq; Tel: +9647703930834; E-mail: almosawiaj@yahoo.com

Received date: 26 August 2020; Accepted date: 19 September 2020; Published date: 30 September 2020

Citation: Al-Mosawi AJ. Childhood Seeligmüller Strümpell Philip Disease: The First Case in Iraq and a Review of the Early Historic Documentation of the Disease in the Literature. Asp J Pediatrics Child Health. 2020 Sept 30;2(2):52-55.

Copyright (C) 2020 Al-Mosawi AJ. This is an open-access article distributed under the Creative Commons Attribution License, which permits unrestricted use, distribution, and reproduction in any medium, provided the original work is properly cited.

\begin{abstract}
Seeligmüller Strümpell Philip disease is characterized by familial progressive spastic paraplegia or paraparesis associated with a progressive deterioration of gait. The disorder is genetically heterogeneous and can be inherited in an autosomal dominant, autosomal recessive or X-linked recessive manner. The mode of inheritance involved has a direct impact on the chances of inheriting the disorder. The cornerstone of treatment is the use of various muscle relaxants. The disorder has not been reported or documented in Iraq. This paper aims to report the first case of childhood Seeligmüller Strümpell Philip disease in an Iraqi girl.

Patients and Methods: A thirteen-year girl with childhood Seeligmüller Strümpell Philip disease who developed systemic lupus erythematosus is described and the early historic documentation of Seeligmüller Strümpell Philip disease in the medical literature is briefly updated.

Results: The diagnosis of Seeligmüller Strümpell Philip disease in this girl was based on clinical findings and supported by electromyography and nerve conduction studies. Brain MRI showed normal findings. Few weeks before the patient was seen, they took her outside Iraq to Medipol Mega complex of Hospitals for treatment. They performed tenotomy and tenoplasty of the hip adductors, achilloplasty, and posterior capsule relaxation. When the girl was first seen at the Children Teaching Hospital of Baghdad Medical City, the parents regretted taking her outside Iraq for treatment as she didn't show any improvement, and was still using the wheelchair.

Conclusion: Unfortunately, the girl was seen too late, and despite consulting many doctors in Iraq and outside Iraq, she didn't receive appropriate evidence based treatment and was treated unsatisfactorily surgically.
\end{abstract}

\section{Keywords}

Seeligmüller-Strümpell-Philip Disease, Historic Update, Iraq, Useless Surgeries 


\section{Introduction}

Seeligmüller Strümpell Philip disease is characterized by familial progressive spastic paraplegia or paraparesis associated with a progressive deterioration of gait resulting from dysfunction of the upper motor neurons in the spinal cord; therefore it is not a form of cerebral palsy which results from brain damage. The condition may have early onset beginning in early childhood at about the age of two years or later onset in adulthood at about the age of 40 years. The disorder is genetically heterogeneous and can be inherited in an autosomal dominant, autosomal recessive or X-linked recessive manner. The mode of inheritance involved has a direct impact on the chances of inheriting the disorder. The cornerstone of treatment is the use of various muscle relaxants [1-13]. The disorder has not been reported or documented in Iraq [14-17]. This paper aims to report the first case of childhood Seeligmüller Strümpell Philip disease in an Iraqi girl.

\section{Patients and methods}

A thirteen-year girl with childhood Seeligmüller Strümpell Philip disease who developed systemic lupus erythematosus is described and the early historic documentation of Seeligmüller Strümpell Philip disease in the medical literature is briefly updated.

\section{Results}

A girl with progressive spasticity in the lower limbs caused by pyramidal tract dysfunction as indicated by increased muscle tone and brisk reflexes experienced progressive gait since early childhood. The parents were consanguineous. During early childhood, she was able to walk on her toes with progressive difficulty, but she had to use a wheelchair before the age of ten. She didn't have speech abnormality or difficulty swallowing. The father confirmed that they consulted many physicians during the previous year; no one prescribed muscle relaxant to reduce spasticity. Left Achillotomy was performed at about the age of five years without experiencing any benefit.

During the previous months, she received a diagnosis of systemic lupus erythematosus after experiencing arthritis and urinary abnormalities. The ANA and Double-stranded DNA tests were both positive and renal biopsy showed mesangial lupus nephritis. The patient was treated with immune suppressive treatments.

Few weeks before the patient was seen, they took her to the Medipol Mega complex of Hospitals for treatment. She was initially admitted to the pediatric neurology department, but she was referred to the department of orthopedics and traumatology. They performed tenotomy and tenoplasty of the hip adductors, achilloplasty, and posterior capsule relaxation.

When the girl was first seen at the Children Teaching Hospital of Baghdad Medical City, the parents regretted taking her to Istanbul for treatment as she didn't show any improvement, and was still using the wheelchair (Fig-1).

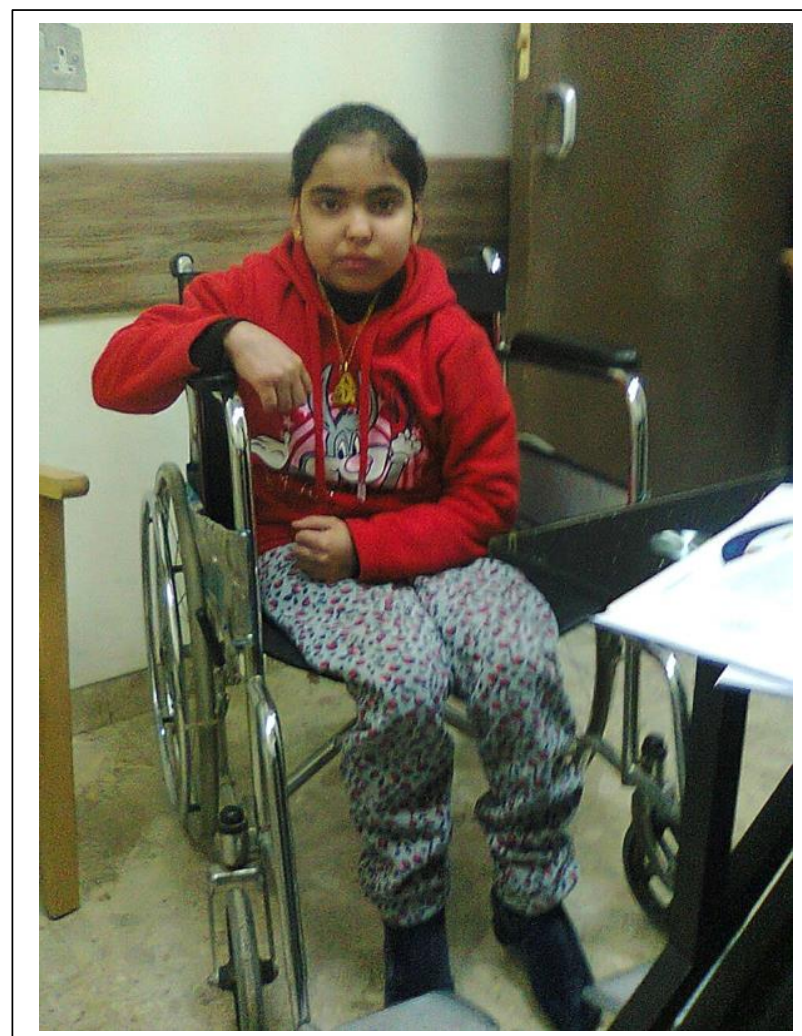

Fig-1: When the girl was first seen, she was still using the wheelchair

The diagnosis of Seeligmüller Strümpell Philip disease in this girl was based on clinical findings and supported by electromyography and nerve conduction studies. Brain MRI showed normal findings. 
Citation: Al-Mosawi AJ. Childhood Seeligmüller Strümpell Philip Disease: The First Case in Iraq and a Review of the Early Historic Documentation of the Disease in the Literature. Asp J Pediatrics Child Health. 2020 Sept 30;2(2):52-55.

\section{Case Report}

\section{Discussion}

In 1876, Adolph Seeligmüller (Fig-2), a German neurologist described a family of four affected children with spasticity. The patients of Seeligmüller had generalized wasting that was probably resulted from disuse atrophy [1]. In 1883, Adolph Strümpell (Fig-3), a German neurologist also reported the condition $[2,3]$. In 1886, Philip described the first case in the United Kingdom [4].
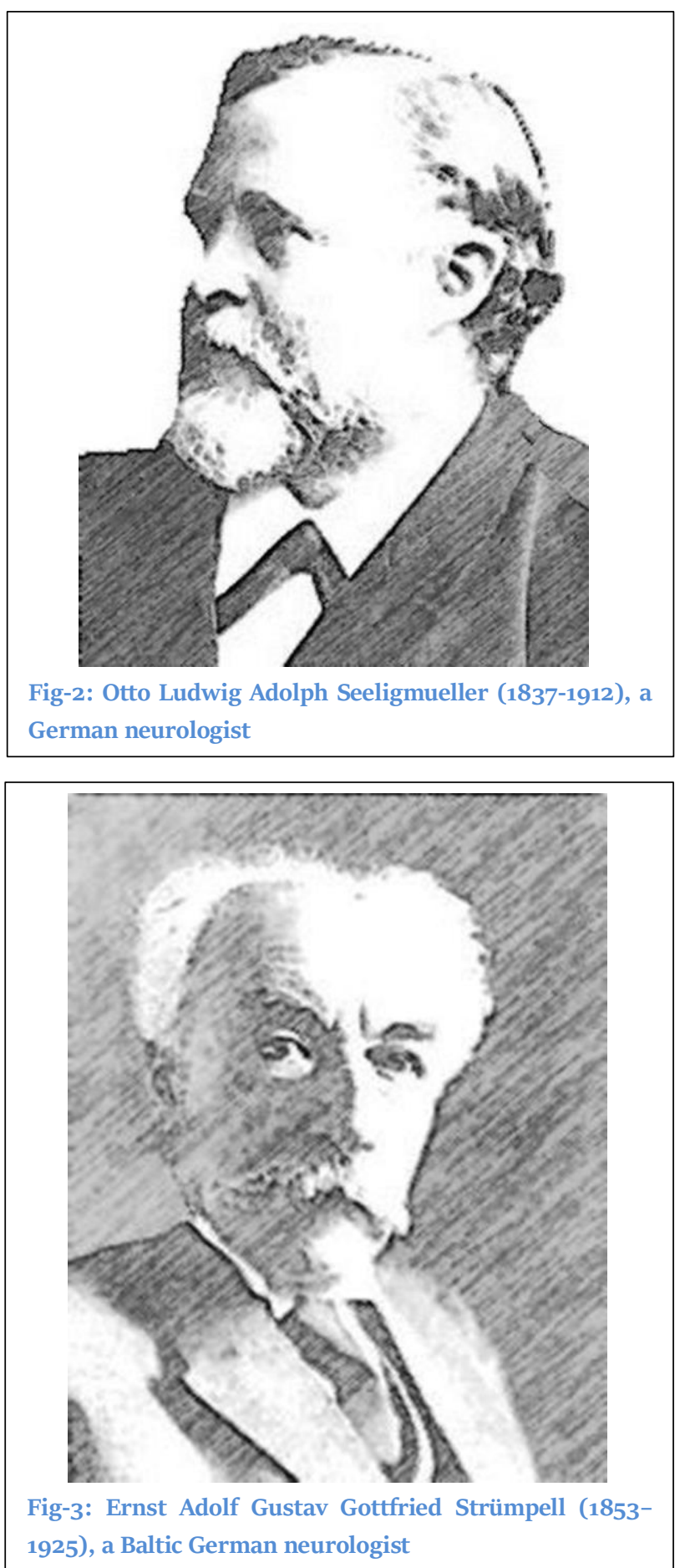

The cornerstone of treatment of Seeligmüller Strümpell Philip disease is the use of various muscle relaxants [11-13].

\section{Conclusion}

Unfortunately, the girl was seen too late, and despite consulting many doctors in Iraq and outside Iraq she didn't receive appropriate evidence based treatment and was treated unsatisfactorily surgically.

\section{Acknowledgement}

The author would like to acknowledge his gratitude for the parents for willingly accepting publishing her photo.

\section{Conflict of interests}

All authors have read and approved the final version of the manuscript. The authors have no conflicts of interest to declare.

\section{References}

[1] Seeligmüller A. Sklerose der seitenstrange des ruckenmards bei vier kindern derselben gamilie. Dtsch Med Wochenshnr. 1876;2:185-86.

[2] Strümpell A. Beiträge zur Pathologie des Rückenmarks. Archiv für Psychiatrie und Nervenkrankheiten. 188o Oct 1;10(3):676-17.

[3] Strümpell A. Zur Kenntniss der multiplen degenerativen Neuritis. Archiv für Psychiatrie und Nervenkrankheiten. 1883 Jun 1;14(2):339-58.

[4] Philip RW. Primary spastic paralysis and pseudohypertrophic paralysis in different members of the same family, with probable heredity in both. Brain. 1886 Jan 1;8(4):520-27.

[5] Simek J. Spastická familiárnä spinálni paralysa [Hereditary spastic paraplegia]. Neurol Psychiatr Ceskoslov. 1948 May;10(5-6):195-201. [PMID: 18108348]

[6] Frola G. Contributo alla conoscenza della cerebroplegia spastica familiare; malattia di Strumpell [Contribution to the knowledge of cerebroplegia familial spastic; Strumpell disease]. Pediatria (Rio). 1948 Aug-Sep;56(7-9):377-85. [PMID: 18101103] [7] Philipp E. Hereditary (familial) spastic paraplegia; report of six cases in one family. N Z Med J. 1949 Feb;48(263):22-25. [PMID: 18120187] 
[8] Bickerstaff ER. Hereditary spastic paraplegia. J Neurol Neurosurg Psychiatry. 1950 May;13(2):134-45. [PMID: 15415753]

[9] Johnston AW, McKusick VA. A sex-linked recessive form of spastic paraplegia. Am J Hum Genet. 1962 Mar;14(1):83-94. [PMID: 14452137]

[10] Roe PF. Hereditary Spastic Paraplegia. J Neurol Neurosurg Psychiatry. 1963 Dec;26(6):516-19. [PMID: 14083224]

[11] Knutsson E, Mårtensson A, Gransberg L. Antiparetic and antispastic effects induced by tizanidine in patients with spastic paresis. Journal of the neurological sciences. 1982 Feb 1;53(2):187-204.

[12] Bes A, Eyssette M, Pierrot-Deseilligny E, Rohmer F, Warter JM. A multi-centre, double-blind trial of tizanidine, a new antispastic agent, in spasticity associated with hemiplegia. Curr Med Res Opin. 1988;10(10):709-18. [PMID: 3286129]

[13] Schüle R, Wiethoff S, Martus P, Karle KN, Otto S, Klebe S, Klimpe S, Gallenmüller C, Kurzwelly D,
Henkel D, Rimmele F, Stolze H, Kohl Z, Kassubek J, Klockgether T, Vielhaber S, Kamm C, Klopstock T, Bauer P, Züchner S, Liepelt-Scarfone I, Schöls L. Hereditary spastic paraplegia: Clinicogenetic lessons from 608 patients. Ann Neurol. 2016 Apr;79(4):64658. [PMID: 26856398]

[14] Al-Mosawi AJ. Genetic and hereditary disorders in Iraqi children. Ann Med \& Surg Case Rep: AMSCR1000011. 2019;2019(02)

[15] Al-Mosawi AJ. Rare genetic disorders in Iraq. 1st ed. Saarbrücken: LAP Lambert Academic Publishing; 2011.

[16] Al-Mosawi AJ. The uncommon and rare genetic disorders in Iraq. 1st ed. Saarbrücken: LAP Lambert Academic Publishing; 2019.

[17] Al-Mosawi AJ. Clinical genetics and dysmorphology: A unique pioneering experiences. $1^{\text {st }}$ ed. Saarbrücken; LAP Lambert Academic Publishing: 2020 . 